\title{
CORPORATIONS: THE THREE-STOCKHOLDERS REQUIREMENT IN NORTH CAROLINA
}

\section{IN Lester Bros. v. Pope Realty $\xi^{2}$ Ins. Co., ${ }^{1}$ the defendant-corporation}

was sued for debts which arose while its shares were held by only two stockholders. The shares held by one of three original stockholders had been purchased by the corporation and had not been resold. The Supreme Court of North Carolina, basing its decision on the earlier case of Park Terrace, Inc. v. Phoenix Indem. Co., ${ }^{2}$ held that, when the number of stockholders of the corporation fell below three, the corporation became dormant and the two remaining stockholders thus became personally liable on the obligations incurred during this period of dormancy.

The court had held in the Park Terrace decision that the pattern of corporate legislation embodied in the North Carolina statutes required that each corporation have a minimum of three stockholders. ${ }^{3}$ This

\footnotetext{
${ }_{250}$ N.C. 565, 109 S.E.2d 263 (1959).

${ }^{2} 243$ N.C. 595 , 91 S.E.2d $584^{\circ}$ (1956).

${ }^{3}$ Eighteen months prior to the suit, all the stock of the Park Terrace corporation was purchased by an individual. As part of the terms of the sale, the buyer signed an agreement to accept the apartment house owned by the corporation "as is" and to release any right to sue because of poor workmanship or defective materials. The buyer, who was the sole stockholder of the corporation, did not bring the suit; instead, the corporation sued the builders of the apartment house for improper workmanship and use of defective materials.

Park Terrace first came before the Supreme Court on appeal from the lower court's overruling of the defendant's motion to bring the buyer into the suit as the real party in interest. The majority of the court ruled that the buyer was not the real party in interest and that, because of the separate entity of the corporation, it could bring the action even though the sole stockholder of the corporation had given a release to the sellers for the very cause of action on which the corporation was now suing.

Justice Bobbitt, dissenting, stated that the separate entity theory was merely a legal fiction and should be disregarded by the courts anytime that recognition of the separate entity would be inequitable. The buyer was attempting to use the separate entity of the corporation to bring indirectly an action that he could not bring directly. In view of the devious use of the corporate entity, the court would have been justified in refusing to recognize the separate entity of the corporation and in requiring that the buyer and sole stockholder be joined as a party.

When the case caine before the Supreme Court, following a judgment for the plaintiff, the court reversed and remanded to the Superior Court for a new trial. The Supreme Court overruled its previous decision on the defendant's motion, and held that the sole stockholder was the real party in interest. The court arrived at this conclusion after examining several of the North Carolina statutes. It was then stated:

"It requires three or more persons to obtain a certificate of incorporation, G.S. 55-2,
} 
holding is contrary to the decisions in most other jurisdictions ${ }^{4}$ and to the rule propounded by leading authorities. ${ }^{5}$ As has been pointed out by numerous decisions, the number three has no magic qualities in the corporate scheme. The number of stockholders might as readily be one or two. ${ }^{6}$

At the time the Park Terrace case was decided, the North Carolina legislature was in the process of revising the state's corporation statutes. The Park Terrace decision precipitated the enactment of section 55-3.1 of the General Statutes, which provides that a corporation's capacity to act as a corporation is not affected when less than three persons acquire all of its stock. Furthermore, this statute also provided that it should operate retroactively. When these facts were drawn to the attention of the North Carolina Supreme Court in the Pope Realty case, it held that the retroactive feature of the statute was unconstitutional because "when plaintiff dealt with Pope the law of this State as declared in the Park Terrace case made him individually liable for the debts he thus created.

and the certificate of incorporation must be signed by a majority of applicants. If one dies before the organization of the corporation, some other person must be designated in his place and stead. G.S. 55-7. The corporation must have at least three directors who manage the affairs of the corporation, G.S. $55-48$, and three officers, provided any two offices may be held by one person. So there must be at least two officers. G.S. 5549. Real estate of the corporation may be conveyed by its president and two stockholders or by the president, attested by the secretary. G.S. 55-40. Three stockholders may call a meeting of the corporation, G.S. 55-6, and a majority of stockholders may dissolve the corporation, G.S. 55-12 r.

"Thus the concept that a corporation is a combination of three or more persons who may operate as a legal entity when chartered so to do threads its way through the cited and practically every other section of our law on corporations. General Statutes, ch. 55 . No lesser number will suffice.

"Not possessing the managerial agencies-stockholders, directors, or officers-contemplated by statute, it can no longer act as a corporation. Its decisions are the decisions of the single stockholder, and its action is his action." Park Terrace, Inc. v. Phoenix Indem. Co., 243 N.C. 595, 597, 91 S.E.2d 584, 586 (1956).

4Majestic Theater Co. v. United Artists Corp., 43 F.2d 991 (D. Conn. 1930); Bachrach v. Allen, 239 Mass. 272, I31 N.E. 857 (I921); Rough v. Breitung, II 7 Mich. 48, 75 N.W. 147 (1898); Brock v. Poor, 216 N.Y. 387 , IxI N.E. 229 (1915); Donaldson v. Andresen, $300 \mathrm{~Pa}$. 312 , I50 Atl. 616 (1930).

5 i Fletcher, Private Corporations $\$ 25$ (perm. ed. r933); Latrin, Corporations 6o (1959); i O'Neal, Close Corporattons $\$ 1.09$ (1958); Stevens, CorporaTIONS $\S \mathrm{r} 5$ (2d ed. 1949). For a critical analysis of the Park Terrace case, see Latty, $A$ Conceptualistic Tangle and the One-or-Tawo Man Corporation, 34 N.C.L. REv. 471 (1956); Note, 34 N.C.L. REv. 53 I (1956); Note, I4 WAsh. \& LeE L. Rev. 72 (1957). See also, Wormser, Piercing the Veil of Corporate Entity, 12 CoLUM. L. REv, 496 (rgiz). Sce also, Ballantine, Corporations $\$ 128$ (rev. ed. 1946), where the general rule is accepted, but with some disapproval.

${ }^{\circ}$ IowA CODE ANN. $\$ 491.2$ (1949), permits incorporation by one person. 
The plaintiff had a vested right in that liability." ${ }^{37}$ By thus attaching the term "vested" to the liability, the court adopted an alternate basis for its holding. 8 This term, however, when used in its constitutional sense, should be limited to a right so substantial that it cannot be taken from a party by legislative action without shocking one's sense of justice and fair play. ${ }^{9}$ If the plaintiff had dealt with the Pope Realty corporation in reliance upon the personal liability of its stockholders as security for the corporate debts, rather than merely happening upon it as a result of the Park Terrace case, then the right might properly be termed vested in the constitutional sense. ${ }^{10}$ The plaintiff, however, had dealt with Pope Realty as a corporation and did not expect that, in the event of the corporation's failure, Pope or the other stockholder would personally assume the corporate obligations.

Both the Park Terrace opinion and the instant opinion are particularly unsatisfactory since, before reaching a decision, the court was aware of the general rule that the separate entity of a corporation will be disregarded when necessary to prevent an inequitable result. ${ }^{11}$ The unnecessary return to the anachronistic three-stockholders concept placed a cloud on all transactions of one- or two-man corporations in North Carolina until the effective date of section 55-3.r. The North Carolina Supreme Court, by holding Pope personally liable, has adhered dogmatically to the concept articulated in Park Terrace, that a corporation cannot exist with less than three stockholders. Consequently, the stockholder-directors in the Pope case were held liable for the corporation's debts when normally the stockholders of a corporation are not liable for its debts.

One had hoped, before the recent Pope Realty case, that the statement in Park Terrace that legislative intention, as manifested by the corporation statutes, required three stockholders, would be restricted as suggested in a recent article. ${ }^{12}$ By adopting the restriction the court could have removed itself from a self-created doctrinal dilemma, but it now appears that the court is taking its previous remarks quite se-

\footnotetext{
7250 N.C. at 568, rog S.E.2d at 266.

${ }^{8}$ The Park Terrace decision was based on supposed legislative intent. See note 3, supra. In the instant case, by applying the term "vested," the court transformed the basis of the holding from legislative intent to a constitutionally protected right.

${ }^{\circ}$ Smith, Retroactive Laws and Vested Rights, 5 Texas L. Rev. 231 (1927). See also, Comment, 34 YALE L.J. 303 (1925).

${ }^{10}$ Hood v. Richardson Realty, 211 N.C. 582, 19 I S.E. 410 (1937).

${ }^{11}$ Park Terrace, Inc. v. Phoenix Indem. Co., 241 N.C. $473,480,85$ S.E.2d 677 , 68 I (I955) (dissenting opinion).

${ }^{12}$ See Latty, supra note 5 .
} 
riously. With each repetition, however, the unfortunate three-stockholders doctrine acquires more strength and stature in North Carolina. Coupled with the dubious "vested rights" rationale for avoiding application of the recent statutory reform, the only solution now seems to be legislative enactment of a short statute of limitations which will remove the cloud cast upon the one- and two-man corporation. 